\title{
The Evolution of Constitutionalism in the PEOPLE'S REPUblic OF CHINA: PAST AND PRESENT
}

\author{
LEIGHA CROUT ${ }^{*}$
}

"For governing the people there is no permanent principle save that it is the laws and nothing else which determine the government. Let the laws roll with the times and there will be good government... But let the times shift without any alteration of the laws and there will be disorder."

Han Fei ${ }^{1}$

Introduction

\section{TABLE OF CONTENTS}

I. A Pre-Constitutional History: Ideologies Informing Modern Constitutionalism

A. The Confucianism v. Legalism Debate

II. The 1945 Constitution: The Westernization of Tradition

A. Ideology and Structure

B. Enumerated Rights

C. Judicial Implementation

III. The 1975 Constitution: The Great Proletarian Revolution

A. Ideology and Structure

B. Enumerated Rights

C. Judicial Implementation

IV. The 1978 Constitution: The Revolution Transitions

A. Ideology and Structure

B. Enumerated Rights and Judicial Enforcement

V. The 1982 Constitution: Into Modernity

A. Ideology and Structure

B. Enumerated Rights

C. Judicial Enforcement

Conclusion

* Leigha Crout is a Senior C.V. Starr Lecturer at Peking University School of Transnational Law in Shenzhen, China and a Research Associate with Oxford University's China, Law and Development Project. She received her Masters in International Development from Cornell University summa cum laude, an LL.M. in Civil and International Human Rights Law magna cum laude from the University of Notre Dame's Klau Center for Civil and Human Rights, and her J.D. from the University of Notre Dame Law School. Her works have been featured in the University of Notre Dame Law School's Journal of International and Comparative Law, the Cornell Center on the Death Penalty Worldwide, and within submissions to the Office of the United Nations High Commissioner for Human Rights, among other forums. She is grateful to Mr. Caleb Christian (Senior C.V. Starr Lecturer, Peking University School of Transnational Law), Mr. Jacob Skebba (Senior C.V. Starr Lecturer, Peking University School of Transnational Law), and Ms. Yiseul Kim (Ph.D. candidate, University of Hong Kong) for their helpful comments and suggestions.

1. Eric W. Orts, The Rule of Law in China, 34 VAND. J. TRANSNAT'L L. 43, 44 (2001) (quoting The Complete Works of Han Fei Tzu 328 (W.K. Liao trans., 1959)). 


\section{INTRODUCTION}

The evolution of constitutional theory and the rule of law in the People's Republic of China is one of the most ideologically divergent progressions of any legal system. ${ }^{2}$ While the concept of an enumerated set of rights and concurrent obligations to which all citizens are bound-indeed, even the concept of fundamental rights in themselves - have been subject to condemnation and disparagement at the nation's most central level, a strong sense of constitutionalism has at the same time become an essential point of development in the view of the modern regime. ${ }^{3}$ In recent years, Chinese constitutional law has rapidly evolved to promote an ideology that is unique from the Soviet and Western thought that shaped the present Constitution's form and content. ${ }^{4}$ As President Xi Jinping stated in his widely published 2019 article on the state of the nation, "[China] must never copy the models or practices of other countries ... We must never follow the path of Western 'constitutionalism,' 'separation of powers,' or 'judicial independence.", In other words, constitutionalism in China is henceforth to be its own distinct model. This explicit departure from Western constitutionalism was reaffirmed in the most recent amendments to the current 1982 Constitution, which defined the leadership of the Communist Party of China (the "CPC") as an essential feature of the country's guiding ideology of socialism and abolished term limits for the President and the Vice President, respectively. ${ }^{6}$

2. Throughout this Article, I will refer to the People's Republic of China as "the PRC" or "China." Orts, supra note 1, at 44. See also Seung-hwan Lee, Liberal Rights Or/And Confucian Virtues?, 36 PHIL. E. \& W. 367 (1996).

3. See, e.g., White Paper: Human Rights in China, Info. Off. Of THE State Council of the PeOPle's RePublic of ChinA (Nov. 1991), http://www.china.org.cn/e-white/7/index.htm [https://perma.cc/W22L-E2PU].

4. See, e.g., M. Ulric Killion, Building Up China's Constitution: Culture, Marxism, and the WTO Rules, 41 LOY. L.A. L. REV. 563, 577 (2008). While somewhat dated, Killion's observations on the unique development of constitutionalism in China is nevertheless revelatory: "Chinese constitutionalism is still developing, but the influence of Marxism impedes its growth toward a more Western model of constitutionalism, as opposed to a variant thereof, such as an economicspecific, culture-specific, or even Marxist model.” Id.

5. 习近平 [Xi Jinping], 加强党对全面依法治国的领导 [Strengthen the Party's Leadership in Governing the Country in Accordance with Law], QS THEORY (Feb. 12, 2019), http://www. qstheory.cn/dukan/qs/2019-02/15/c_1124114454.htm [https://perma.cc/PE8S-QBAF]. This Article is in part an excerpt of President Xi Jinping's speech in August of 2018. At the time of this speech, the Commission for Law-Based Governance had just been established, with President $\mathrm{Xi}$ as its head. See also Charlotte Gao, Xi: China Must Never Adopt Constitutionalism, Separation of Powers, or Judicial Independence, THE Diplomat (Feb. 19, 2019), https://thediplomat. com/2019/02/xi-china-must-never-adopt-constitutionalism-separation-of-powers-or-judicialindependence/ [https://perma.cc/5XYA-SXUQ].

6. 中华人民共和国宪法修正案 [Amendments to the Constitution of the People's Republic of China], Xinhua News AgEncy (Mar. 11, 2018), http://www.xinhuanet.com/ politics/2018lh/2018-03/11/c_1122521235.htm [https://perma.cc/HW5V-B29A]. See also Annotated Translation: 2018 Amendment to the P.R.C. Constitution (Version 2.0), THE NPC 
As an inorganic legal transplant with several theoretically and administratively diverse predecessors, the current Constitution was not immediately recognized as a foundational and controlling source of law. ${ }^{7}$ Nevertheless, China's national government has adopted several initiatives and public acknowledgment of the governing document in recent years to encourage further constitutional engagement. ${ }^{8}$ For example, on December 4, 2014, the nation celebrated its first "Constitution Day." Issuing a rallying call for an increased awareness of the Chinese constitution and its imperatives, President Xi Jinping encouraged schools, government offices, and companies owned and operated by the State to engage in activities facilitating a renewed familiarity with the text of the State's Constitution. ${ }^{10}$ The extended holiday has been condemned by advocates of human rights and critics of the modern Chinese government as a mere artifact of propaganda developed by the dominant Communist Party. ${ }^{11}$ However, the necessity of increasing public awareness of constitutional guarantees is not disputed. ${ }^{12}$

International constitutional scholars suggest various definitions of constitutionalism. John Elster of the University of Chicago considers constitutionalism "a state of mind - an expectation and a norm-in which

OBSERVER (Mar. 2018), https://npcobserver.com/2018/ 03/11/translation-2018-amendment-tothe-p-r-c-constitution/ [https://perma.cc/69HM-2G3Q]. See generally XIANFA (1982) (China).

7. Id. at 2. See also M. Ulric Killion, China's Amended Constitution: Quest for Liberty and Independent Judicial Review, 4WASH. U. Glob. Stud. L. Rev. 43, 50-51 (2005).

8. In December 2019, over twenty million Chinese students were reported to have read the Constitution simultaneously in different Internet meetings throughout the nation. Shi Yinglun, China Strengthens Education on Constitution for Students, XINHUA (Dec. 3, 2019, 7:20 PM), http://www.xinhuanet.com/english/2019-12/03/c_138602845.htm [https://perma.cc/UJ83Z2N5]. See also Li Xia, China unveils first "Constitution Week" Campaign, XINHUA (Dec. 3, 2018, 4:43 PM), http://www.xinhuanet.com/english/2018-12/03/c_137648035.htm [https:// perma.cc/2L2L-ERD2].

9. Carrie Gracie, Has President Xi Jinping Achieved His China Dream?, BBC News (Dec. 19, 2014), http://www.bbc.com/news/world-asia-china-30544572 [https://perma.cc/M8YQX4D7].

10. School children were directed to read the document in its entirety, as well as cite several major provisions from memory. Yeshi Dorje \& Anqi Hu, China Celebrates First Constitution Day, Voice OF AMERICA (Dec. 4, 2014), https://www.voanews.com/east-asia/china-celebratesfirst-constitution-day [https://perma.cc/4D5V-GLBD].

11. Constitution Day was established in the midst of an intensive anti-corruption and transparency campaign initiated in response to the mass detainment of Chinese government officials on charges of corruption and other practiced abuses of public trust. Id. See also Ting Shi, China Celebrates Constitutional Rights Citizens Are Arrested For, Bloomberg Bus. (Dec. 4, 2014), http://www.bloomberg.com/news/articles/2014-12-04/china-shows-shawshankredemption-to- celebrate-citizens-rights [https://perma.cc/E8LS-3E7C].

12. See Shi, supra note 11. In pursuit of further public acknowledgment of the new holiday, "Constitution Publicity Week" was established in 2018 "to foster respect, study, observation, safeguarding and application of the Constitution." Fifth Constitution Day \& First Constitution Week, China DAILY (Dec. 2018), http://www.chinadaily.com.cn/m/chinalic/node_53013711.htm [https://perma.cc/Y9PB-PT28]. See also Qianfan Zhang, A Constitution Without Constitutionalism? The Paths of Constitutionalism in China, 8 OXFORD INT'L J. CON. L. 950, 95860 (2010). 
politics must be conducted in accordance with standing rules or conventions, written or unwritten, that cannot be easily changed." 13 Across the vast pond, Vratislav Pechota, a scholar of Czech origin, has stated that constitutionalism "is a system of commonly shared values and judgments about the political organization sustaining the statehood, as well as a set of agreed-upon principles creating legitimacy." ${ }^{14}$ Finally, Jiang Shigong of Beijing University describes constitutionalism not as one specific theory of law but as an overarching concept of norm structures and value systems with specific sub-categories. ${ }^{15}$ While these scholars vary in social and educational backgrounds, there is an ideological "through line" to these proposed understandings - the notion of collective adherence to shared values. As this Article will describe, the current and previous Chinese constitutions have in large part rejected these definitions and made way for a new type of "constitutionalism" to arise.

This Article will critically trace and analyze the constitutional development of the People's Republic of China (the "PRC") throughout its unique history of codification. The concept of "constitutionalism" discussed throughout will refer to the collective belief in the values espoused by the government and the legitimacy of authority exercised by the changing regimes. The Work will focus specifically on the enumerated constitutional rights and how the enforcement of these elicited, or failed to elicit, an authentic and publicly shared sense of constitutionalism. To this end, this Article will discuss the pre-constitutional and dynastic history of China prior to the establishment of the PRC, as well as the eras of the 1954 Constitution, the 1975 Constitution, the 1978 Constitution, and the 1982 Constitution.

Each section regarding a particular Constitution will evaluate three basic elements essential to constitutionalism: first, the reigning ideology which influenced the sociopolitical context within which the constitution was formed and promulgated; next, the presence — or lack thereof — of fundamental human rights, freedoms, and entitlements; and finally, the role of the judiciary in the vindication of any enumerated rights or entitlements. Special attention will be allocated to the present Constitution and the modern political developments that grant insight into constitutionalism's status and potential growth in the nation. In outlining the PRC's evolving dedication to principles of constitutionality, this Article will endeavor to illuminate the unique adaptations of the principles throughout the nation's history, and in so doing, provide a more profound understanding of modern-day constitutional rhetoric and change.

13. John Elster, Constitutionalism in Eastern Europe: An Introduction, 58 U. CHI. L. REv. 447, 465 (1991).

14. Dana Dallas Atchinson, Notes on Constitutionalism for a $21^{\text {st- }}$ Century Russian President, 6 CARdozo J. InT'L \& Comp. L. 239, 244 (1998) (citing Vratislav Pechota, Czechoslovak Constitutionalism, CzechoslovaK \& Cent. EuR. J. 1 (1991)).

15. Jiang Shigong, Chinese-Style Constitutionalism: On Backer's Chinese Party-State Constitutionalism, 40 MoD. CHINA 133, 134 (2014). 


\section{A PRE-CONSTITUTIONAL HISTORY: IDEOLOGIES INFORMING MODERN CONSTITUTIONALISM}

In assessing the growth of constitutionalism in the People's Republic of China, it is important to first analyze the nation's history prior to the development of its initial constitution. In early China, two predominant legal theories exerted substantive influence on the maturation of the Chinese legal system, namely, Confucianism and Legalism. ${ }^{16}$ Representing polarized conceptions of "law," scholars of these two philosophies engaged one another in a fierce debate extending over several millennia of legal change. ${ }^{17}$ Although the formal legal doctrine advocated by the Legalist school, known as $f a$, officially predates the impact of Confucianism on the early, unified China, Confucianism nevertheless wrought the greater inspiration on the PRC's modern constitutional theory due to its comprehensively influential nature. ${ }^{18}$

Confucianism is not merely a theory of law; it is a sociopolitical tradition that is intended to direct all aspects of individual conduct, interpersonal relationships, and societal order through the imposition of certain, specific categories of obligations and expectations. ${ }^{19}$ These obligations, called $l i{ }^{20}$ primarily manifest between individual categories of persons, including, for instance: father and son, teacher and pupil, and husband and wife. ${ }^{21}$ As a tradition ground in post-conflict ideology, strict adherence to the standards of behavior prescribed by $l i$ is intended to facilitate the maintenance of social harmony through deference to principles of peace, cohesion, and forbearance. ${ }^{22}$ It is by means of acting within these principles of $l i$ that one may achieve the true actualization of the self, termed jen, or ultimate benevolence. ${ }^{23}$ This

16. Konrad Zweigert \& Hein KötZ, An InTroduction to COMPARATIVE LAw 288 (Tony Weir trans., 3rd ed. 1998).

17. Jacques deLisle, China's Approach to International Law: A Historical Perspective, 94 AM. SOC'Y INT'L L. Proc. 267, 268 (2000).

18. H. Patrick Glenn, Legal Traditions of the World 349 (5th ed. 2014). See also ZWEIGERT \& KÖTZ, supra note 16, at 290.

19. GLENN, supra note 18 , at 328.

20. "Li" has developed into varying concepts of obligation in those nation states that have been influenced by the teachings of Confucius. For example, the Japanese legal tradition prescribes "giri," or the duty to sustain an attitude of consistent loyalty or gratefulness. Id.

21. ZWEIGERT \& KÖTZ, supra note 16, at 288.

22. "The most important goal of man must therefore be to keep his thoughts, feelings, and actions in perfect accordance with cosmic harmony; in particular men must so conduct themselves as not to disturb the natural balance of their existing relations." Id.

23. Jen is also often referred to as ren in contemporary translations. History and Literature: Ren (Benevolence), Cultural ChINA (2013), http://www.cultural-china.com/ chinaWH/html/ en/43History984.html. Several English concepts have been suggested as an adequate interpretation of jen; though varying, all in some way promote the shared ideal of selflessness in each act. P.C. Chang, representative of the People's Republic of China in the initial drafting stages of the Universal Declaration of Human Rights, referred to jen as "two-man mindedness," or holding others in same esteem and affording the same consideration as one owes oneself. MARY Ann Glendon, A World Made New: Eleanor Roosevelt and the Universal Declaration OF HuMAN RightS 67 (2001). 
common aspiration guides adherents to Confucian thought in initially establishing and maintaining a lasting, peaceful balance. ${ }^{24}$

Conversely, the school of Legalism understands the nature of humankind to be cruel, immoral, and generally unlawful. ${ }^{25}$ In order to compensate for the overly capricious and naturally destructive tendencies of man, an orderly society must implement the law as a tool of instruction and control. ${ }^{26}$ This role of law in the Legalist tradition necessitates the imposition of rigorous standards of general conduct, the swift enforcement of harsh penalties for those who fail to conform, and the total assumption of legislative acts as guideposts for behavior. A key difference between Confucianism and Legalism is their respective proclivity for an official and codified set of laws. ${ }^{27}$ Whereas adherents to Confucianism resist the reference to formal legal procedure and statutes for the resolution of internal disputes, instead preferring to settle arguments through discussion and controlled mediation, ${ }^{28}$ Legalism requires the development of a strong administration, detailed edicts, and reference to legal bodies regarding any disputes that might arise concerning property or entitlements. ${ }^{29}$

Legalist thought exerted substantive influence on the first government of the unified China under the Qin Dynasty in 221 B.C., reigning in the latter half of the tumultuous Warring States period. ${ }^{30}$ Operating upon the theory that separate territories previously owned in the entirety by individual warlords might only be unified by strict adherence to a new centralized system of administration and under the threat of collective coercion for nonperformance under the restructured government, draconian policies were developed and enforced throughout the Qin Dynasty. ${ }^{31}$ Though China did not consider the adoption of a controlling constitution at this time, it has been acknowledged that the close adherence to Legalist theory significantly assisted in the structural

24. ZwEIGERT \& KöTZ, supra note 16, at 288.

25. Yuri Pines, The Stanford Encyclopedia of Philosophy: Legalism in Chinese Philosophy, STAN. U. (Nov. 16, 2018), https://plato.stanford.edu/archives/win2018/entries/chinese-legalism/ [https://perma.cc/4NMJ-3CDL].

26. J. A. G. Roberts, A CONCISE History OF CHinA 20-21 (1999).

27. ZwEIGERT \& KÖTZ, supra note 16, at 289.

28. Alternate dispute resolution was abundant in early China. When individuals within a group would enter into a dispute that would prove unresolvable between the arguing parties alone, a neutral head of a household or an individual held in high esteem within the community would be asked to preside over the two as an impartial third party. The impartial third party would then facilitate a mutually agreeable outcome, or in the least attempt to preserve a climate of reciprocal respect in accordance with the requirements prescribed by $l i$. Id. at 291. A Chinese proverb is indicative of this mentality: "Even the wisest judge cannot adjudicate family disputes." Joy L. Chia, Piercing the Confucian Veil: Lenahan's Implications for East Asia and Human Rights, 21 AM. U. J. GENDER SOC. POL’y \& L. 379, 379-80 (2012).

29. ROBERTS, supra note 26.

30. Orts, supra note 1, at 53; see also Pines, supra note 25, at 26.

31. Confucian texts and manuscripts were confiscated and burned in an effort to repress any dissention from either a social or philosophical standpoint. ZWEIGERT \& KÖTZ, supra note 16, at 289. 
preparations for an initial constitutional instrument. ${ }^{32}$

Though the rigid structure of the Legalist Qin Dynasty in part contributed to its success as the initial governing force of "China," this rigidity also contributed to its rapid downfall in 206 B.C. ${ }^{33}$ Upon the Qin Dynasty's collapse, the rising Han Dynasty instituted rule by Confucian ideals of noninterference, individual reflection, and reverence for the grander community, a reign which would extend for more than four centuries. ${ }^{34}$ However, upon the expiration of the Han Dynasty, the unification achieved by the Qin splintered once more into warring territories or "kingdoms," and China did not again experience substantive development of principles of constitutionality until the chaotic governance of the Qing Dynasty. ${ }^{35}$

The Qing Dynasty, China's last imperial dynasty prior to the intervention of Western States, initiated its rule in 1644 and ended in $1912 .{ }^{36}$ War and internal revolution affected China's constitutionalism throughout this timeframe. First, the Japanese Imperial Army triumphed over the Chinese forces in the First Sino-Japanese War. ${ }^{37}$ This unexpected defeat demonstrated to the Chinese people the growth in strength and economic fortitude that the small island nation experienced throughout the Meiji Restoration period of Westernization. ${ }^{38}$ Domestic military experts attributed the defeat not to military deficiencies but to "the outdated and corrupt state system" notorious for its exploitation of State funds. ${ }^{39}$ This initial observation was coupled with Qing-

32. In Henrique Schneider's article Legalism: Chinese-Style Constitutionalism?, he discusses how the Legalist theory, especially as promoted by its two foremost scholars, Han Fei and Shang Yang, paved the way for the development of a uniquely Chinese constitutionalism. Schneider's thesis:

Many legal practitioners and scholars claim that China lacks the powers driving constitutionalist thinking and therefore seems not to be able to implement a constitution comparable to "Western" documents, or in other words, a liberal constitution. Often, these claims are supported by arguments focusing on the history of Chinese legal philosophy, which did not seem to mobilize essential resources for the development of constitutionalism-style thinking .... This article tries to show how legalists ... created a framework very similar to some of the desiderata considered to be philosophical preconditions for constitutionalist thinking.

Henrique Schneider, Legalism: Chinese-Style Constitutionalism? 38 J. CHINESE PHIL. 46,46 (2011).

33. Orts, supra note 1 , at 54.

34. ZWEIGERT \& KÖTZ, supra note 16 , at 289.

35. Id.

36. Timeline of Chinese History and Dynasties, Asia for Educators, Colum. U. (2009), http://afe.easia.columbia.edu/timelines/china_timeline.htm [https://perma.cc/VHL6-EF7X].

37. Shannon Tiezzi, Chinese Strategists Reflect on the First Sino Japanese War: A Collection of Essays on the Sino Japanese War of 1894-95 Has Obvious Implications for Modern China, ThE DiPlomat (Apr. 18, 2014), http://thediplomat.com/2014/04/chinese-strategists-reflect-onthe-first-sino-japanese-war/ [https://perma.cc/GB9V-3EF3]. See also Pu Zengyuan, The Movement for Constitutionalism and Constitutions in Twentieth-Century China, 17 BULL. AusTL. Soc. LEG. PHIL. 162, 163 (1992).

38. Tiezzi, supra note 37.

39. Economists have stipulated that the true salaries of Qing era government officials, including the acceptance of bribes and land exploitation, amounted to more than 18 times the "legal" salary at the time. Shawn Ni \& Pham Hoang Van, High Corruption Income in Ming and 
era sentiment, which equated the success of foreign powers to their constitutionbased regimes. ${ }^{40}$ In response to this exposure and growing dissatisfaction with China's traditionalist adherence to imperialism, reformists such as Kang Youwei and Sun Yat-Sen began to advocate for a system of organized constitutional governance. ${ }^{41}$

However, the constitutional reformists were met with intense opposition from multiple nationalist movements endeavoring to preserve the Chinese feudal system. ${ }^{42}$ In 1900, the patriotic Boxer Rebellion, led by Yi He Tuan, was initiated against the creeping Western powers. ${ }^{43}$ Though quelled promptly by foreign forces and the Qing government, the Boxer Rebellion delivered a shock to China's legal system. ${ }^{44}$ Faced with calls for modernization and stress from the forced observance of unequal peace treaties that effectively splintered the newly reunified territories, the government drafted a document which, at least on its face, purported to commence institutional change. This document aimed to satisfy parties advocating reform and preserve national unity. ${ }^{45}$ To this end, the Qing Dynasty promulgated the Principles of Constitution made by Imperial Order in 1908, which announced a "preparation period" for constitutionalism to last nine years. ${ }^{46}$

Though substantively based upon the European-influenced Meiji Constitution of Japan, the Principles did not embody ideals of modernization or a liberal conception of government. ${ }^{47}$ The primary objective of the 1908 Principles of Constitution was to preserve the principles of feudal autocracy that secured the rule of the Qing. ${ }^{48}$ Unsatisfied by this "false constitutionalism," Sun Yat-Sen energized his revolution. The people ultimately rejected the

Qing China, 81 J. of Dev. Econ. 316, 323 (2006). See also Zhu Ningshu, Generals' Articles Inspire Retrospection on Sino Japanese War, XINHUA (Apr. 17, 2014), http://www.china. org.cn/world/2014-04/17/content_32126631.htm [https://perma.cc/72X7-UBMS].

40. Killion, supra note 7, at 50.

41. Zengyuan, supra note 37, at 163.

42. Empress Dowager Cixi, who had accrued significant governmental authority through her regency, spearheaded the movement against Emperor Guangxu's "Hundred Days Reform." Assuming authority once more through staunch support from conservative governmental figures, she reigned until her death in 1908. Nevertheless, she, too, advocated for constitutionalism, stating that "our hope too is in a constitution." Amanda Fiegl, Cixi: The Woman Behind the Throne; The Concubine Who Became China's Last Empress, SMithsonian Mag. (Mar. 1, 2008), http://www.smithsonianmag.com/history/cixi-the-woman-behind-the-throne-22312071/?noist $=\&$ page $=2$ [https://perma.cc/KH23-BBHX]; see also L. R. O. Bevan, China's Constitutions, 2 Chinese Soc. \& Pol. Sci. Rev. 89, 92 (1917).

43. Boxer Rebellion, HistORY (June 7, 2019), http://www.history.com/topics/boxer-rebellion [https://perma.cc/Z93N-EHDJ].

44. Zengyuan, supra note 37 , at 163.

45. Orts, supra note 1 , at 56.

46. Zengyuan, supra note 37, at 163-64.

47. Jerome Alan Cohen, China's Changing Constitutions, 1 Nw. J. INT'L L. \& Bus. 57, 59 (1979).

48. Zengyuan, supra note 37, at 164 .

49. Id. 
Principles, preferring instead to continue their advocacy for a true constitution that would stimulate collective Chinese acceptance of the benefits that arose from achieving "modernity." 50 Sensing potential upheaval, the Qing Dynasty attempted a final appeal to the rising constitutionalists: the Nineteen Constitutional Articles. ${ }^{51}$

The Nineteen Constitutional Articles, much like their preceding model, were recognized by the people as a farcical attempt to placate the revisionists whilst maintaining the traditionalist method of governance through the prescription of a "constitutionalist monarchy." 52 The document, as well as the reign of the Qing, was summarily rejected and ultimately overthrown by Sun Yat-Sen's movement. ${ }^{53}$ On January 1, 1912, the Republic of China was established with Sun Yat-Sen as its provisional president. ${ }^{54}$ However, this unification did not last; China soon fell back into an additional decade of provincial "warlordism," subsequently complicating any proposed developments of constitutionalism. ${ }^{55}$ Prior to the establishment of a "permanent" constitution in 1923, a surplus of prospective constitutions was drafted, considered, and ultimately passed over as inferior to the strong Western instruments. ${ }^{56}$ For instance, the 1923 Constitution of the Republic of China, though a "splendid document" 57 enumerating democratic values on par with Western governments, was entirely unsuited for the chaotic realities of the bellicose Chinese State. ${ }^{58}$ Demanding a parliamentary democracy to mirror those found in Europe, this document's function resembled that of an aspiration rather than a functioning document for the thinly aligned Chinese territories. ${ }^{59}$

At this point in the history of China, it was difficult to ascertain the support of the people for the establishment of a constitution, as well as the potential functionality of any branches for lack of governing articles or lack of adherence to such articles. Thus, it is fair to describe the development of "constitutionalism" in China at the time as uniquely stunted as compared to the constitutional developments of Western States and Japan. ${ }^{60}$ The subsequent

50. Cohen, supra note 47 , at 59.

51. Zengyuan, supra note 37, at 164.

52. Id.

53. Cohen, supra note 47 , at 59.

54. Zengyuan, supra note 37 , at 164.

55. Orts, supra note 1 , at 56.

56. Cohen, supra note 47, at 59. One Western expert noted that, "[o]ne is apt to get confused with the welter of constitutions that have come and gone." Id. (citing Bevan, supra note 42, at 90.). This constitution was also called the "Constitution of Bribery," drafted by the government of President Cao Kun, who had elected himself via bribery. Zengyuan, supra note 47, at 165.

57. Cohen, supra note 37, at 56.

58. Id.

59. Id. at 60 .

60. During this time, Japan had established the Meiji Constitution, the first of its two constitutions. This document, which experienced success relative to its regional counterparts, remained in effect until the drastic reformations undertaken in 1946. See Fumiko FukaseIndergaard \& Michael Indergaard, Religious Nationalism and the Making of the Modern Japanese State, 37 THEORY \& SOC'y 343, 373 (2008). 
constitutional instruments following the 1923 Constitution and prior to the establishment of the People's Republic of China were similar to the former document: largely idealistic, reactionary, and rife with impracticality. ${ }^{61}$ Upon the victory of Mao Zedong and the Chinese Communist Party against the forces directed by Chiang Kai-shek in the Chinese civil war, three constitutions were passed: the Provisional Constitution of the Republic of China in the Period Under Political Tutelage in 1931, Constitution of the Republic of China in $1947,{ }^{62}$ and the Common Program in $1949 .{ }^{63}$

A few important points must be acknowledged concerning the great impact of the aforementioned documents on Chinese constitutionality. First, the drafters' intent and understanding of constitutionalism differed radically depending upon the political circumstances of the time, thereby impacting the text of each document. ${ }^{64}$ Regime changes, rife with conflicting philosophies, prohibited the establishment of a common theoretical baseline that might have provided a stronger foundation for a unifying document. This capricious attitude left the definition of Chinese constitutionalism muddied by the constant shift of the "founding principles of the nation." ${ }^{\prime 65} \mathrm{Next}$, the dearth of participation of the people in each reiteration of the constitutional instruments, exacerbated by the promotion of Western ideology, prevented an integral facet of "constitutionalism" from being realized; namely, the development of a certain set of principles or regulations that the governed recognize as sovereign. Finally, the general lack of applicability to the then-current Chinese government institutions further removed the idea of a preeminent document from the minds of the people. Instead, collective recurring failures to integrate these ideas and institutions strengthened the preexisting skepticism for Western jurisprudence. ${ }^{66}$

This doubt presented very serious difficulties for any future constitutional endeavors by China. In order to reassert the value of a unifying, superseding document, the Chinese government would be obligated to either fully dedicate itself to the text with a strong sense of commonly shared ideals or draft a functional document that more accurately reflected the current governmental regime. This inherent skepticism, as well as the dichotomy between textual idealism and practicality, have played major roles in China's constitutional growth and continue to be primary themes in the nation's constitutional discourse. Experimentation with these different formulations has led the nation to its modern conception of governance. The next section will highlight the struggle to achieve a tenable balance within the four constitutions promulgated

61. Zengyuan, supra note 37, at 165-67.

62. Significantly, this document represented an initial integration of the West and East methodologies of governance, and still governs Taiwan today. Id.

63. This constitution primarily functioned as a transitional document. XIANFA (1946) (China); see also Cohen, supra note 47, at 61.

64. Cohen, supra note 47, at 60-1.

65. Id. at 61.

66. Id. at 62 . 
by the People's Republic of China and the development of constitutionalism throughout their respective control.

\section{THE 1954 CONSTITUTION: THE WESTERNIZATION OF TRADITION}

\section{A. Ideology and Structure}

Perhaps unsurprisingly, the 1954 Constitution of the PRC differed substantially from its Republican precursors as a unique amalgamation of the foreign and the familiar. ${ }^{67}$ Though still a "borrowed" document somewhat removed from China's more traditional conceptions of law, the 1954 text instead emulated the ideology of Eastern European countries - specifically, principles of socialism and communism. ${ }^{68}$ In February of 1950, just after the triumph of the Communist forces in the Chinese civil war, the state formally aligned itself with the Union of Soviet Socialist Republics (U.S.S.R. or the Soviet Union) in signing a Treaty of Friendship, Alliance and Mutual Assistance. ${ }^{69}$ In light of this new alliance and ideological reformation, the Constitution reflected a strong sense of communitarianism. ${ }^{70}$ Unlike the more liberal Western traditions, which focus on individual rights and entitlements, this Constitution adopted a more collective stance on social and economic initiatives, including the right to work and the right to health. ${ }^{71} \mathrm{By}$ sharing similarities to the Confucian decentralization of the individual, as well as the Legalist conception of a strong State, this Constitution boasted more recognizable principles to those it governed. $^{72}$

In addition to the transition to a more practical ideological conformity, the 1954 Constitution conversely acted as a formal introduction to policies foreign to the Chinese legal system, with a view to the full assumption of Marxist philosophy. ${ }^{73}$ In an attempt to establish the "people's democratic dictatorship" "74 of China - a play on words from the Soviet "dictatorship of the proletariat" the 1954 Constitution adopted a substantial portion of its text from the 1936 Constitution of the U.S.S.R. ${ }^{75}$ The proposed justification for the document's inorganic content was the facilitation of both social and economic

67. See generally XIANFA (1954) (China).

68. Cohen, supra note 47 , at 62.

69. In exchange for financial and military assistance in the event of regional conflict with Japan, the parties agreed to a coordinated response to addressing problems of international concern. See generally Sino-Soviet Treaty of Friendship, Alliance and Mutual Assistance, Feb. 14, 1950, China \& U.S.S.R.

70. XIANFA, supra note 67, arts. 9, 93.

71. Id.

72. See generally XIANFA, supra note 67.

73. Cohen, supra note 48, at 62.

74. Id. at 62-63.

75. See generally XIANFA, supra note 67; see also KonSTITUTSIIA SSSR (1936) [KonST. SSSR] [U.S.S.R. CONSTITUTION]. 
transformation in line with the dominant Communist Party. ${ }^{76}$ Economic revitalization, with particular regard to agricultural and industrial progress, was soon achieved upon promulgation. ${ }^{77}$ This Constitution and its derivative Soviet principles reigned for more than two decades, leaving a decided mark on the development of constitutionalism in the PRC. ${ }^{78}$ The conjunction of conformance to then-modern Chinese practice and the introduction of Communist ideology presented a rather odd but nevertheless successful regime.

Concerning structure, the 1954 Constitution of the PRC established a division of governmental powers that would be preserved throughout the three successive versions. ${ }^{79}$ Similar to the Supreme Soviet in the U.S.S.R., ${ }^{80}$ legislative authority was to vest solely in the National People's Congress (the "NPC"). ${ }^{81}$ The NPC was comprised of "deputies," or representatives elected by the provinces of China, who served terms extending over four years. ${ }^{82}$ Power to execute the laws under the NPC's directives was imparted to the State Council of the People's Republic of China and its primary officers: the Premier, the Vice Premiers, the Ministers, the Chairmen of Commissions, and the Secretary General. ${ }^{83}$ Though the PRC was not a federal state like the Soviet Union, the "local people's congresses" and "local councils" were based upon the Soviet model. ${ }^{84}$ Finally, the capacity to preside over cases or controversies, again under the supreme authority of the NPC, was imparted to the Supreme People's Court of the People's Republic of China. ${ }^{85}$ Like the U.S.S.R., China's courts did not possess the capacity to review legislation promulgated by the NPC on the basis of constitutionality. ${ }^{86}$ The executive and judicial branches, along with the Supreme People's Procuratorate of the People's Republic of China, worked in tandem to ensure national deference to the incumbent Communist party. ${ }^{87}$

\section{B. Enumerated Rights}

Though entrenched in a communitarian ideology that typically downplays individual entitlements, the 1954 Constitution of the PRC enumerates a remarkably wide commitment to a number of individual rights. ${ }^{88}$ This

76. Cohen, supra note 47 , at $64-65$.

77. Id. at 65.

78. XIANFA, supra note 67.

79. See generally id. See also XIANFA (1975) (China); see also XIANFA (1982) (China).

80. U.S.S.R. Constitution, supra note 75. See also Cohen, supra note 47, at 63.

81. Hereinafter "NPC." XIANFA arts. 22-23 (1954) (China).

82. Id. arts. 22-24.

83. Id. arts. 47-48.

84. Cohen, supra note 47 , at 63.

85. XIANFA arts. 73, 79 (1954) (China). There are four levels of courts in the PRC: the Supreme People's Court, the high courts, the intermediate courts, and basic courts. See Gerd Ruge, An Interview with Chinese Legal Officials, 61 CHINA Q. 119-20 (1975).

86. XIANFA, supra note 85, art. 80. See also Cohen, supra note 48, at 63.

87. XIANFA, supra note 85 , art. 81.

88. Id. arts. 85-102. 
emergence is particularly notable for the prior role, or lack thereof, of rights in Chinese society until the promulgation and enforcement of this instrument, as well as the advent of sustained Western influence. ${ }^{89}$ In the Confucian tradition, to which China had steadfastly adhered and continues to observe, the concept of civil and political rights are not naturally occurring ideas. ${ }^{90}$ The Westerninfluenced idea of fundamental "rights" in law owed to the people by the governing body, as noted in the previous section of this Article, ${ }^{91}$ does not reflect the understanding of Confucian disciples. Instead, all members of the community owe one another obligations of mutual respect, social conformity, and deference in times of interpersonal conflict. ${ }^{92}$ Whereas the West would emphasize the importance of what Isaiah Berlin would designate as "negative rights," or the facilitation of freedoms through lack of governmental regulation in areas such as civic participation, land ownership, and freedom of speech, the Chinese government would prefer to emphasize those "positive" rights that regulate and facilitate the growth of the community, such as rights relating to education, work, and social welfare. ${ }^{93}$

In contrast to the widely held perception of liberal "rights" in China, an entire chapter within the 1954 Constitution is dedicated to the foundation and enforcement of the rights of the people. ${ }^{94}$ Further, instead of subordinating "negative" rights in the civil and political realm, which was to be expected given Confucianism's acclimation to the peaceful pursuit of the common good, negative rights were promoted alongside positive entitlements. ${ }^{95}$ The right to

89. For further discussion on the PRC's objection to the regime of human rights, with particular regard to the international human rights institutions, see generally World Conference on Human Rights, Report of the Regional Meeting for Asia of the World Conference on Human Rights, U.N. Doc. A/Conf.157/ASRM/8 (Apr. 7, 1993).

90. Lee, supra note 3, at 367.

91. See discussion Section I.

92. In scholarship, this acclimation to the collective well-being is commonly referred to as a tradition of rights or obligations centered around the "common good." As opposed to liberal traditions, which feature the dignity of the individual as the core source of human rights, these traditions instead look to the grander community in establishing and promoting a specific regime of rights. Lee, supra note 2, at 367.

93. Typically, civil and political rights are referred to as "negative" rights, whereas economic, social, and cultural rights are deemed to be "positive." Though this distinction has been criticized as arbitrary and unfounded for the underlying similarities of both sets of rights in modern scholarship, the reference persists. ISAIAH BERLIN, TWO CONCEPTS OF LIBERTY: FOUR ESSAYS ON LIBERTY 128, 130 (1969); see also White Paper: Human Rights in China, supra note 3. For a critique of the traditional "civil and political" and "economic, social, and cultural distinction," see generally Stephen P. Marks, The Past and Future of the Separation of Human Rights into Categories, 24 MD. J. INT'L. L. 209 (2009).

94. XIANFA arts. 85-102 (1954) (China).

95. See generally id. 
vote, ${ }^{96}$ guaranteed freedom from arbitrary arrest, ${ }^{97}$ the right to unrestricted social expression, ${ }^{98}$ the right to religious freedom, ${ }^{99}$ and the unqualified right to privacy ${ }^{100}$ were perhaps more emphasized than their "positive" counterparts. ${ }^{101}$ This notion is observable via two primary aspects of the 1954 version: first, negative rights were listed before the positive social, cultural, and economic subjects, and civil and political entitlements were broader in scope and application. ${ }^{102}$ This is particularly notable in Article 87, which enumerated the following rights all within its text: "freedom of speech, freedom of the press, freedom of assembly, freedom of association, freedom of procession and freedom of demonstration. To ensure that citizens can enjoy these freedoms, the state provides the necessary material facilities."103

An additional unique aspect of Chapter 3 of this Constitution is its requirement that "citizens of the People's Republic of China must abide by the Constitution and the law, observe labor discipline, observe public order and respect public morality" outlined in Article 100. ${ }^{104}$ Though seemingly selfexplanatory to citizens already attuned to governance by a preeminent document such as a constitution, the inclusion of this verbiage is a testament to the PRC's distinctive flavor of constitutionalism at the time.

\section{Judicial Implementation}

The introduction of the explicit invocation of the constitution by judges in the adjudication of disputes did not occur until 2001, with prior jurisprudence actually limiting the scope of the courts' authority to employ the document in guiding litigation procedures. ${ }^{105}$ One of the initial decisions of the Supreme

96. The constitutional guarantee to this right also incorporated the general principle of nondiscrimination, with a special emphasis of nondiscrimination on the basis of sex: "All citizens of the People's Republic of China, who have reached the age of eighteen, have the right to vote and stand for election, irrespective of their nationality, race, sex, occupation, social origin, religious belief, education, property status, or length of residence, except insane persons and persons deprived by law of the right to vote and stand for election. Women have equal rights with men to vote and stand for election." Id. art. 89.

97. Id. art. 86.

98. Id. art. 95 .

99. Id. art. 88.

100. $I d$. art. 90 .

101. See generally id.

102. Id. arts. 85-90.

103. Id. art. 87.

104. Id. art. 100 .

105. This statement is made in reference to the curious case of Qi Yuling, also known as "China's Marbury v. Madison." Acclaimed by both domestic and international scholars as the first and foremost constitutional ruling in Chinese history, Qi Yuling will be discussed in depth later in this Article. See Albert Y. Chen, Constitutionalism in Asia in the Early TwentyFIRST CEnTury 122 (2014); see also Thomas E. Kellogg, The Death of Constitutional Litigation in China?, 9 CHINA BRIEF 4 (Apr. 2, 2009), http://www.jamestown.org/programs/chinabrief/ 
People's Court of the PRC, in the form of a reply to the Xinjiang Higher People's Court's inquiry on the subject of criminal law and its intersection with the Chinese constitution, prescribed the following:

To the Xinjiang Higher People's Court: We have received . . . your Court report no. 336 . . . The Constitution of the People's Republic of China is the fundamental law of our nation, and it is the mother of all other laws. While delivering his report on the draft Constitution of the PRC, Chairman Liu Shaoqi noted that: "it is the most important question in the life of our nation, regulating what types of behavior are legal, or what statues must effectuate and what they must prohibit." Regarding penal matters, [the Constitution] does not regulate any issues relating to determination of guilt or punishment, and so therefore we agree with the opinion of your court, that the Constitution cannot be cited in criminal decisions. ${ }^{106}$

Notable here is the implicit deference to the legislative edicts issued by the incumbent National People's Congress. ${ }^{107}$ In the absence of citations to the active constitution in the process of criminal convictions, the courts are left to apply either statutes or regulations promulgated by either the NPC or the Standing Committee. ${ }^{108}$ This procedure has led to the critique of China both domestically and internationally as being governed not by the rule of law, rather by the "rule of man." Specifically, the rule of the Chinese Communist Party, which consistently dominates the NPC. ${ }^{109}$ Without the courts' intervention in the preservation of fundamental rights enumerated within the constitution, this left a remarkable gap in the practical guarantee of such entitlements.

The 1954 constitution, though flawed by its failure to reflect the legal character of China adequately, successfully governed the unified PRC for over 20 years. ${ }^{110}$ Despite the apparent practicality of the instrument, the Communist Party, led by Mao Zedong, drafted a new and radical constitution meant to

single/?tx_ttnews\%5Btt_news\%5D=34791\&amp;cHash=da4e9\#.VtCZP5MrJPO[https://perma. cc/UFF3-B5WW].

106. Thomas E. Kellogg, Constitutionalism with Chinese Characteristics? Constitutional Development and Civil Litigation in China, 7 INT. J. CON. L. 215, 221 (Mar. 6, 2009).

107. Id. at 215 .

108. Id. at 221.

109. In 1978, Shuming Liang, renowned philosopher, was the first to explicitly challenge the "rule of man" in the $5^{\text {th }}$ National Committee of CPC, stating that:

The rule of man has reached the end in China and has caused disasters and chaos. It was a painful lesson and the 'Great Cultural Revolution' has raised our awareness of the detriment of the 'rule of man' and necessitated the establishment of the 'rule of law' in China. It is necessary to transform China from the 'rule of man' to the 'rule of law.' It has been proven that the rule of man was a dead end. It is the Rule of Constitution and Law as the governing strategy that will help us move forward. This transformation is inevitable in light of historical development.

Ruizhi Zhang, The Special Role of Foreign Legal History in China in the Construction of a New Legal System, 6 FronT. L. China 481, 486-7 (2011).

110. See generally XIANFA (1954) (China). See also Cohen, supra note 47, at 62. 
instigate a new era of legal development that would impact China even until the present day. ${ }^{111}$

\section{THE 1975 CONSTITUTION: THE GREAT PROLETARIAN REVOLUTION}

\section{A. Ideology and Structure}

The 1975 Constitution was drafted in the spirit of the Great Proletarian Revolution, commonly referred to as the Cultural Revolution in contemporary scholarship. ${ }^{112}$ Initiated in 1966 by Mao Zedong and his steadfast supporters in the wake of the resounding failure of the Great Leap Forward, ${ }^{113}$ the Great Proletarian Revolution was designed to eradicate all semblances of both traditional Confucian and Western ideology. ${ }^{114}$ Through the destruction of these former traditions through a "Pro-Legalist" campaign, ${ }^{115}$ Mao Zedong hoped to promote and sustain the absolute supremacy of Communist philosophy. ${ }^{116}$ To this end, all schools from primary to post-graduate level were closed in order to properly "mobilize" the ideologies of the youth, ${ }^{117}$ certain jobs were temporarily suspended, ${ }^{118}$ and reeducation was prolific in this new culture of purification through destruction. ${ }^{119}$

Perhaps no occupation was impacted more than that of attorneys. ${ }^{120}$

111. See generally Marc Blecher, China Against the Tides: Restructuring through REVOLUTION, RADICALISM AND REFORM 77-86 (1997).

112. Another term of reference is the "Great Proletarian Cultural Revolution." Walter Gelhorn, China's Quest for Legal Modernity, 1 J. ChINESE L. 1, 7 (1987). See also H. ZweIGERT $\&$ H. KoTZ, supra note 16, at 314.

113. The Great Leap Forward was a campaign aiming to affect economic, social, and cultural growth in the PRC. Initiated by Mao Zedong and his commissioners, its primary goal was to transform the agrarian economy into one of lucrative industry. Noting a particularly bountiful harvest, Mao Zedong prescribed particular methods of farming that were ultimately ineffective, resulting in the Great Famine of 1958 to 1962, as well as the death of over 30 million individuals (due both to starvation and the draconian policies enforced by Mao Zedong's government). See Frank Dikötter, Mao's Great Leap to Famine, N.Y. TimES (Dec. 15, 2010), http://www.nytimes. com/2010/12/16/opinion/16iht-eddikotter16.html?_r=0 [https://perma.cc/SVU4-SHLN ]. See also Mao and the Great Leap Forward, Rutgers: Newark Coll. ArTs \& Scis. (2013), http://www.ncas.rutgers.edu/mao-and-great-leap-forward.

114. Al Young, The Continuing Lack of Independence of Chinese Lawyers, 18 GEO. J. LEGAL ETHICS 1133, 1135 (2005).

115. Shao-Chuan Leng, The Role of Law in the People's Republic of China as Reflecting Mao Tse-Tung's Influence, 68 J. CRIM. L. \& CRIMINOLOGY 356, 369 (1997).

116. Id. See also Cultural Revolution, HistORY (2009), http://www.history.com/topics/ cultural-revolution [https://perma.cc/FE8K-5GUB].

117. Orts, supra note 1 , at 57-58.

118. HISTORY, supra note 116.

119. Orts, supra note 1 , at 57-58.

120. Id. 
Throughout the era of the Great Proletarian Revolution, "lawlessness"121 and the breakdown of formal legal procedure were emphasized by propagandists as the new ideal. ${ }^{122}$ Lawyers, professors of law, and other legal professionals were therefore seen as unnecessary and a collective impediment to the progress of the Revolution. ${ }^{123}$ Upon this basis, attorneys and those others versed in the law were involuntarily sent to "reeducation facilities," or labor camps based in rural farming areas and factories. ${ }^{124}$ This, in addition to the nationwide closure of law schools, ensured the gradual demise of the law as a profession. ${ }^{125}$ Ultimately, the Chinese legal system was so thoroughly impacted by the Great Proletarian Revolution that some external observers described it as "nonexistent." ${ }^{\text {"126 }}$ It is in this context that the next Constitution of the PRC, the Constitution of 1975, was promulgated and quite heavily enforced.

The structure of the government as between the legislative, executive, and judicial branches in the 1975 Constitution is similar to that of its precedent laid out in the 1954 Constitution, with an important caveat: the authority of the National People's Congress became unrestricted and absolute. ${ }^{127}$ While the 1954 Constitution outlined sixty-three articles on the structure of government in the PRC as well as functions and applicable limitations, the 1975 Constitution described the new structure of the PRC in only ten. ${ }^{128}$ In addition to including the prior functions listed in the former instrument, the Communist Party built upon its authority through several reconstructions of power. ${ }^{129}$ First, NPC delegates were limited to members of the Communist Party of China. ${ }^{130}$ Second, the terms of delegates were lengthened to five years. ${ }^{131}$ Third, all branches of the government were to operate at the will of the NPC. ${ }^{132}$ Finally, the NPC was permitted to "exercise such other functions and powers as the National People's Congress deems necessary." 133 With no further elaboration on what constitutes "necessary" in the Constitution, this language inevitably implies an unconditional authority imparted to the Communist Party of China. ${ }^{134}$

The PRC's adoption of the 1975 Constitution is particularly disquieting for

121. Jerome Alan Cohen, Tiananmen and the Rule of Law, in The Broken Mirror: China After Tiananmen 323, 328 (George Hicks ed., 1990).

122. Orts, supra note 1 , at 57-58.

123. Id. at 58.

124. Id. at 57-58.

125. Id.

126. Id. Judge Jack Weinstein stated that "There was really no Chinese legal system after the Cultural Revolution.” Jack B. Weinstein, Some First Impressions of the Legal System in Three Chinese Cities, 24 Brook. J. InT'L L. 221, 229 (1998).

127. See XIANFA art. 21-84 (1954) (China); see also XIANFA art. 16-25 (1975) (China).

128. See generally XIANFA (1954) (China).

129. XiAnFA art. 16-25 (1975) (China).

130. Id. art. 16.

131. Id.

132. Id. arts. 18, 19, 20, 25.

133. Id. art. 17.

134. Id. 
its nature as a post-hoc legitimization of the actions retroactively taken, and to be taken upon ratification, by the Chinese Communist Party. There are a multitude of concerns that may have factored into this decision to "constitutionalize" certain actions taken by the NPC, including the need for external, international governments to see the PRC as legitimate and adhering to the rule of law, devotion to socialist doctrine, substantiating the impact of the Great Proletarian Revolution, and the desire for the people to understand the power of the then-modern government as legitimate. Whatever the primary reason for this action, the adoption of the 1975 Constitution spoke to the development of constitutional law at the time; the PRC was continuing the growing tradition of constitutionalism, even throughout its Revolution-and these marks are yet visible today.

\section{B. Enumerated Rights}

The fundamental rights in this iteration of the PRC's constitution differed considerably in form. ${ }^{135}$ The 1975 Constitution reduced the number of Articles from an ample 19 to merely four. ${ }^{136}$ Various rights were notably absent in the rendition, such as the right to inherit title to private property, ${ }^{137}$ the "right of residence" 138 as opposed to the right to asylum, and the entirety of the rights described in Article 95 of the 1954 Constitution, which "safeguards the freedom of citizens to engage in scientific research, literary and artistic creation and other cultural activities. The state encourages and assists the creative endeavors [sic] of citizens in science, education, literature, art, and other cultural pursuits."139 However, many more liberal entitlements were preserved through an effective consolidation of several rights into one article. ${ }^{140}$ This is particularly true of Article 28, which includes the rights to freedom of speech, dialogue, press, as well as "assembly, association, procession, demonstration and the freedom to strike, and enjoy freedom to believe in religion and freedom . . . to propagate atheism . . . freedom of person and their homes shall be inviolable. No citizen may be arrested except by decision of a people's court or with the sanction of a public security organ."

135. See XIANFA arts. 85-102 (1954) (China); see also XIANFA art. 26-29 (1975) (China).

136. See generally XIANFA (1975) (China).

137. XIANFA arts. 85-102 (1954) (China).

138. Id. art. 99. See also XIANFA arts. 29 (1975) (China).

139. XIANFA art. 95 (1954) (China).

140. See generally XIANFA arts. 26-29 (1975) (China).

141. Id. art. 28. In addition to rights a distinctive obligation was included as well. Article 26 describes that "[i]t is the lofty duty of every citizen to defend the motherland and resist aggression. It is the honourable obligation of citizens to perform military service according to law." Id. art. 26. 


\section{Judicial Implementation}

The declining state of the Chinese legal system during the Great Proletarian Revolution also drastically affected the judiciary. ${ }^{142}$ Enforcement of basic constitutional rights often occurred through extrajudicial (even extralegal) means of resolution in many, if not most, cases. ${ }^{143}$ Within the constitution, the role of the courts was reduced from twelve articles to simply one: Article $25 .{ }^{144}$ This Article enhances judicial deference to the legislative authorities, outlining that the courts "[exercise] judicial authority. The people's courts are responsible and accountable to the people's congresses and their permanent organs at the corresponding levels. The presidents of the people's courts are appointed and subject to removal by the permanent organs of the people's congresses at the corresponding levels." 145 Accordingly, the functions of the courts were quite limited; many cases were handled by "basic-level administrative units and mass organizations," 146 or organs established for the maintenance of public security. ${ }^{147}$ Under this Constitution, the courts were almost exclusively involved in divorce proceedings and important criminal cases. ${ }^{148}$ Effectively, the NPC was the branch responsible for the promulgation, rescission, and enforcement of rights. This potential for abuse of public trust proved irresistible throughout Mao Zedong's reign and led to the violation of some of the most basic human rights, including the right to life. ${ }^{149}$

The decline and ultimate death of Mao Zedong coincided with the termination of his regime. ${ }^{150}$ The failed Great Proletarian Revolution had garnered enough public opposition to organize a new regime with a focus on social reparations and economic reform. ${ }^{151}$ Following the arrest of his "Gang of

142. Leng, supra note 115 , at 361.

143. Id.

144. See XIANFA arts. 73-84 (1954) (China); see also XIANFA art. 25 (1975) (China).

145. XIANFA art. 25 (1975) (China).

146. Leng, supra note 115 , at 361.

147. Id.

148. Id.

149. The right to life is one of the few jus cogens rights recognized today. This means that even if it is not included within a constitution, legislation, or administrative regulation, the governing authority in any State must nevertheless respect it. RESTATEMENT (THIRD) FOREIGN Relations L. OF THE U.S. $§ 102 \mathrm{cmt}$. K (AM. LAW InST. 1987). During the Great Proletarian Revolution, it is estimated that 1.5 to 3 million people were killed. These numbers are attributable to governmental policy, extrajudicial killings, and the famine brought on by the failed Great Leap Forward. Jane Perlez, A Leader in Mao's Cultural Revolution Faces His Past, N.Y. TIMES (Dec. 6, 2013), http://www.nytimes.com/2013/12/07/world/asia/a-student-leader-in-maos-culturalrevolution.html [https://perma.cc/US5F-6C3C].

150. Luisetta Mudie, Elite Marks Gang of Four Fall, Radio Free Asia (Oct. 7, 2011), https://www.rfa.org/english/news/china/four-10072011153943.html/[https://perma.cc/URU2-

X6LA].

151. See Perlez, supra note 149. Chen Yun, a former Communist Party leader, famously made the following statement on Mao's legacy: "Had Mao died in 1956, his achievements would have been immortal. Had he died in 1966, he would still have been a great man but flawed. But he died in 1976. Alas, what can one say?" Big Bad Wolf, Economist (Aug. 31, 2006), 
Four," the notorious officials closest to Mao and responsible for the mass violations of constitutional rights, another major constitutional movement took place in the PRC. Seeking to mitigate the decimation of the legal system as a result of the Great Proletarian Revolution, the Constitution of 1978 was drafted and promulgated by the NPC. ${ }^{152}$ Due to the transitional nature of the document, the proceeding section will be comparatively brief and consolidated.

\section{THE 1978 CONSTITUTION: THE REVOLUTION TRANSITIONS}

\section{A. Ideology and Structure}

The drafting of the 1978 Constitution was motivated in part by a large-scale effort to "de-Maoize" 153 the nation in the wake of the destructive Great Proletarian Revolution. ${ }^{154}$ Contrarily, the document also pronounced an unwavering dedication to "Marxism-Leninism-Mao Zedong thought." $155 \mathrm{Ph}$. de Herr, Second Secretary of the Royal Netherlands Embassy at Peking, PRC, at the time of this constitution's promulgation, summarized the underlying philosophy as follows:

Since [Mao's death and the arrest of the Gang of Four] . . . deMaoization ... gained speed ... with little diminution of his name and status. On the contrary, the more his radical policies [were] dismantled, especially in the cultural and educational field, the more his name or his thoughts [were] invoked to legitimize these changes. The ambiguity finds its origin in the composition of the present leadership. This consists on the one hand of "réhabilitès" who suffered from the Cultural Revolution, and on the other hand of those who rose because of it. A denunciation of Mao's radical policies and the Cultural Revolution would taint the legitimacy of the latter group's present position, the devastating effects of the last ten years of political turmoil are now invariably attributed to the nefarious influence of the "gang of four."156

The structure of the 1978 Constitution was again reminiscent of the prior two versions, with the executive and judicial branches operating under the National People's Congress and the Standing Committee. ${ }^{157}$ Although this

https://www.economist.com/books-and-arts/2006/08/31/big-bad-wolf[https://perma.cc/2WB9ME3P].

152. XIANFA art. 25 (1978) (China).

153. Ph. de Herr, The 1978 Constitution of the People's Republic of China, 4 REv. Socialist L. 309, 310 (1978).

154. Id.

155. XIANFA, supra note 152, art. 2.

156. Id.

157. XIANFA, supra note 152, arts. 20-43. 
governmental structure promoted consistency, it faced similar issues to its predecessor. Namely, it did not adequately engage its constituents; this primary inefficacy, as well as political shifts on the world stage, ensured that the reign of this document was limited.

\section{B. Enumerated Rights and Judicial Enforcement}

In the 1978 Constitution, the number of articles pertaining to rights was expanded once more, spanning from Article 44 to Article $60 .{ }^{158}$ Much of the language was reinstituted from the 1954 Constitution, along with additional language detailing methods for implementation and enforcement of the outlined rights. ${ }^{159}$ The judiciary's responsibilities in adjudicating issues regarding constitutional rights were somewhat restored in this constitution in the three applicable articles, though still practically limited in application. ${ }^{160}$ Due to the brief reign of this constitution, from 1978 to 1982, as well as the judiciary's slow recovery from the Great Proletarian Revolution, cases documenting the courts' acclimation to preserving rights are few and far between. The people of the PRC were yet unsatisfied with the character of the document, which still retained the vestiges of a revolution past. Progress - especially social and economic - was not only the foremost desire of citizens but also necessary to ensure that the State was capable of broadening its influence in the era of globalization, on par with major world powers. That desire was expressed for a new document, one that would propel the PRC into a new era of powerful change.

\section{THE 1982 CONSTITUTION: INTO MODERNITY}

\section{A. Ideology and Structure}

The 1982 Constitution of the PRC may be best described as a veritable mélange of ideologies and formal legal rules. Article 1 establishes the nation as a "socialist state under the people's democratic dictatorship led by the working class and based on the alliance of workers and peasants."161 Though adherence to socialist doctrine was still compulsory, a number of distinct institutional changes affected the application of its principles. ${ }^{162}$ Between 1982 and 2017, the Constitution was subject to four separate Amendments embracing liberal ideals since its ratification, growing increasingly similar to its Western counterparts with each adaptation. ${ }^{163}$ Notably, these revisions endeavored to establish the

158. Id. arts. 44-60; see also XIANFA art. 26-29 (1975) (China).

159. XIANFA arts. 20-43 (1978) (China). See also Jill Barrett, What's New in China's Constitution?, 9 Rev. Socialist L. 305, 308 (1983).

160. XIANFA, supra note 159 , arts. 41-43.

161. XIANFA art. 1 (1982) (China).

162. Zhang, supra note 13, at 958-9.

163. Id. at 959. 
rule of law, to protect and promote human rights, to recognize title to private property, and to legitimize private business enterprises. ${ }^{164}$ Though this increasing liberalization affected the development of the State, the PRC maintained its former structure outlined in the 1954 Constitution that called for ultimate respect of the NPC as the primary organ of governmental authority and did not incorporate the concept of judicial review. ${ }^{165}$

More recent amendments to the Constitution cement the steadfast control of the NPC and diverge from the general trend towards a more Western understanding of constitutionalism. Indeed, recent scholarship has speculated that modern Chinese constitutionalism has become increasingly entangled with the leadership of the Communist Party of China, the longtime foremost party of the NPC. ${ }^{166}$ The founding ideology of this Constitution has had a gradual but notable evolution "phasing in" Party thought and influence to key portions of the document. The increasing aggrandizement of the Party is especially apparent in the 2018 Amendments. ${ }^{167}$ As mentioned in the Introduction of this Article, the 2018 Amendments directly imbued Party control into the first Article of the document. ${ }^{168}$

Prior to the 2018 Amendments, the second paragraph of Article 1 read: "The socialist system is the basic system of the People's Republic of China. Disruption of the socialist system by any organization or individual is prohibited." 169 The article now reads: "The socialist system is the basic system of the People's Republic of China. The defining feature of socialism with Chinese characteristics is the leadership of the Communist Party of China. Disruption of the socialist system by any organization or individual is prohibited." $" 170$ The renewed phrasing elicits numerous outstanding impressions. First, the very foundations of socialism in China are now intertwined with the leadership of a political party, ensuring its status as the key governmental figure for the foreseeable future. Disruption of the "socialist system"- -which now explicitly includes the leadership of the CPC - is "prohibited." While it may be too early to observe the precise impact of this alteration on constitutionalism, it is apparent that the $\mathrm{CPC}$ will play the leading role in its development.

164. Id.; See generally. XIANFA, supra note 161.

165. XIANFA, supra note 161, art. 57.

166. The aggrandizement of the CPC and its own constitutionalism in relation to its organizing document (the "CPC Constitution") has also been a subject of discussion in recent years. While beyond the scope of this paper, it's been acknowledged that the CPC's Constitution will grow increasingly relevant to its State counterpart and, in turn, society's general perception of constitutional governance. See Larry Catá Backer, Chinese Constitutionalism in The "New Era:" The Constitution in Emerging Idea and Practice, 33 ConN. J. INT'L L. 163, 170 (2018) [hereinafter Backer, Chinese Constitutionalism in The "New Era"].

167. Annotated Translation: 2018 Amendment to the P.R.C. Constitution (Version 2.0), supra note 7. See also XIANFA (1982) (China).

168. XIANFA, supra note 167.

169. Id.

170. Id. 


\section{B. Enumerated Rights}

In keeping with its initial tradition of allying itself in text to a plethora of Western precepts in order to facilitate modernization, the 1982 Constitution of the PRC demonstrates a prominent allegiance to fundamental civil, political, and economic rights, mirroring the guarantees of nations such as the United States. ${ }^{171}$ Unlike preceding constitutions, however, there is an exceptional and strong limitation on the exercise of freedoms - the enjoyment of liberties may not "infringe upon the interests of the state, of society and of the collective, or upon the lawful freedoms and rights of other citizens." 172 The justification for this exception is rooted in the traditional Confucian tenet of collective noninterference and advancement, though the Constitution explicitly aligns itself to socialist theory. ${ }^{173}$ The apparent contrast between the inclusion of a wide variety of rights as well as an overarching limitation without the capacity to be challenged is also exemplary of China's modern objection to the international human rights regime, indicating that rights at the international level are subject to this same domestic check. ${ }^{174}$

Instead of a gradual rescission from this understanding, the nation has instead enforced this notion of "qualified" constitutional rights at the central level. The State's particular model of rights has been coined as "rights with Chinese characteristics" by the PRC in modern dialogue. ${ }^{175}$ In its "White Paper on Human Rights" produced in 1991, the government acknowledged the progress of the State in terms of democratic development and economic success. ${ }^{176}$ It then emphasized that the vast entitlements described in the Constitution are limited to preserve the accomplishments of the State, in the sense that they must not "infringe upon the interests of the state, of society or of the collective." ${ }^{177}$ This has been reaffirmed in subsequent documents and official statements, including the Bangkok Declaration of $1993,{ }^{178}$ a product of

171. Id. arts. 33-56.

172. Id. art. 51. Another qualification is the citizen's obligation to guard "state secrets," retaining the potential to be used liberally as a restriction on rights. $I d .=$ art. 54 .

173. Id. art.1; see also U.N. Doc. A/Conf.157/ASRM/8, supra note 89.

174. See generally U.N. Doc. A/Conf.157/ASRM/8, supra note 89 (demonstrating that China took a stance on universal human rights in accordance with the U.N.).

175. See, e.g., H.E. Wang Yi, Minister of Foreign Affs. of the People's Republic of China, Advance the Global Human Rights Cause and Build a Community with a Shared Future for Mankind (Dec. 7, 2017), in Permanent Mission of the People's Republic of China to the U. N. OfF. At Geneva AND Other InT'L Orgs. IN Switz. (Dec. 13, 2017), http://www.chinaun.ch/eng/dbtyw/rqrd_1/thsm/t1519207.htm.[ https://perma.cc/65WP-3SFZ].

176. White Paper: Human Rights in China supra note 3, art. 3.

177. Id. art. 2.

178. China participated heavily in the creation of this Declaration and imbued within it a similar exception to rights, which was articulated within the Constitution. For example, Paragraph 8 reads: "while human rights are universal in nature, they must be considered in the context of a dynamic and evolving process of international norm-setting, bearing in mind the significance of national and regional particularities and various historical, cultural and religious backgrounds." 
the Regional Meeting for Asia of the World Conference on Human Rights. More recently, H.E. Le Yucheng, Head of the Chinese Delegation and Vice Foreign Minister on the Adoption of the UPR Outcome Report on China at the United Nations, stated in an address that "the path of human rights development with Chinese characteristics, one that takes the national conditions as the foundation" has been a successful one. ${ }^{179}$

Given the consistency with which the PRC has held this perspective on constitutional rights and their limitations, this particular form of rights implementation is not likely to recede unless the leadership of the NPC was to change fundamentally.

\section{Judicial Enforcement}

While lacking the authority of judicial review, it is under this Constitution that the Chinese courts begin to assume a limited role in the application of the Constitution in the context of civil and criminal disputes. Perhaps best known as the case that instigated modern constitutional jurisprudence in the PRC is $Q i$ Yuling v. Chen Xiaoqui, also known as "China's Marbury v. Madison." 180 In this case, Chen Xiaoqui stole classmate Qi Yuling's admissions letter to a specialized school, leading Qi to believe that she had failed the entrance exam. ${ }^{181}$ Chen went on to study under Qi's name, eventually securing a position at a bank. ${ }^{182}$ Upon realizing Chen's actions years later, Qi brought suit, alleging damages for theft. ${ }^{183}$ The Supreme People's Court, to the surprise of the nation, invoked the constitutional right to education under Article 46. ${ }^{184}$ This was the first time in history that the SPC invoked the Constitution in a case since the Constitution's administration is seen as a subsidiary organ of the NPC and the Standing Committee.

Though this opinion was later withdrawn and courts have since refrained from such an explicit invocation of the Constitution or constitutional rights in subsequent rulings, there is still some anticipation that the SPC will once more engage the Constitution in judicial discourse. ${ }^{185}$ Recent reforms to the judiciary have taken place between 2014 and 2018, the "third round" in a series of judicial

Michael C. Davis, Human Rights in Asia: China and The Bangkok Declaration, 2 BufF. J. INT'L L. 215, 216(1996); see U.N. Doc. A/Conf.157/ASRM/8, supra note 89.

179 H.E. Le Yucheng, Head of Chinese Delegation, Meeting People's Aspiration for a Better Life Through Continued Progress on Human Rights in China, in PERMANENT Mission OF THE People's Republic of China to the U.N. OfF. at Geneva and Other Int'l Orgs. in Switz. (Mar. 15, 2019), http://www.china-un.ch/eng/dbtyw/rqrd_1/thsm/t1661099.htm [https://perma. cc/2GYS-36LS].

180. Zhang, supra note 12, at 960.

181. Id.

182. Kellogg, supra note 104, at 231.

183. Zhang, supra note 12, at 960.

184. Id.; See also XIANFA art. 46 (1982) (China).

185. Zhang, supra note 12, at 960. 
reform efforts promoted by the government. ${ }^{186}$ Justice Zhou Qiang, President of the Supreme People's Court and the nation's highest-ranking adjudicator, summarized the reforms as follows:

[T]he establishment of judicial accountability system, (2) the strengthening of human rights protection in criminal proceedings, (3) the adjustment of the court system, to (4) the response to social public opinion, (5) the resolution of the enforcement dilemma of court judgments, (6) the expansion of the court's open justice, (7) the development of the court's informationization and intelligence. ${ }^{187}$

Some of these reforms are worth further mentioning for their marked departure from previous administrations and serve as an insight into the nature of common problems experienced within the judiciary. ${ }^{188}$ Under the auspices of establishing a judicial accountability system, extraneous layers of supervision were eliminated when judges of lower courts were no longer required to receive approval from a higher ranking judge or the court president prior to their final ruling coming into effect. ${ }^{189}$ To improve human rights in criminal proceedings, illegally obtained evidence was more formally excluded from legal proceedings; the presumption of innocence was emphasized as a necessary principle; and thirty-seven known wrongfully convicted persons received official pardons for the misadministration of justice. ${ }^{190}$ During this time, two hundred seventy court

186. The first two rounds of reform took place between 2004 and 2008, respectively, and addressed items such as the implementation of a uniform examination system for judges, strengthening ethics training and continuing education for both judges and law enforcement officers, and raising the minimum qualifications for judicial staff. See 中国的司法改革白皮书 [The People's Republic of China, Judicial Reform in China], InFo. OfF. OF THE STATE CounCIL (Oct. 2012), http://english.www.gov.cn/archive/white_paper/2014/08/23/content_281474983043 170.htm [https://perma.cc/E8A9-QH6B].

187. Progress of China's Judicial Reform in 2015, The Supreme People's CT. of The PeOPLE's RePUBlic OF ChinA (Mar. 21, 2016), http://english.court.gov.cn/2016-03/21/content_ 23999270.htm [https://perma.cc/RU37-MGLD].

188. See id. See also Highlights of China's Judicial Reform Progress in 2018, XINHUA (Jan. 15, 2019), http://www.xinhuanet.com/english/2019-01/15/c_137745598.htm [https://perma.cc/ BP8V-23DP].

189. Progress of China's Judicial Reform in 2015, supra note 187; see also China Grants More Judicial Independence to Judges Amid Reform, The Supreme People's CT. of The PEOPLE'S RePUBlic OF CHINA (Oct. 17, 2014), http://english.court.gov.cn/2014-10/17/content_ 21819062.htm [https://perma.cc/W33L-KYK5].

190. Other notable reforms included, among others, resolving the "enforcement dilemma" of court judgments, especially for cases involving property and monetary damages. A "disciplinary network" was created for debtors who failed to comply with judicial mandates, and "Enforcement Tribunals" were organized to address any complaints by debtors throughout the enforcement process. Prior to this reform, law enforcement officers and personnel were tasked with handling these complaints. 杜国栋 [Guodong Du] and 余萌 [Meng Yu], Courts in China's Judicial Reform (The Third-round Judicial Reform During 2014-2017), CHINA JusT. OBSERVER (Oct. 29, 2018), https://www.chinajusticeobserver.com/a/courts-in-china-s-judicial-reform-the-third-roundjudicial-reform-during-2014-2017 [https://perma.cc/7T57-NPPY]. 
officials were also formally admonished by the NPC for violating the Communist Party Code of Conduct. ${ }^{191}$ Observers believe that consistent implementation of like reforms will serve to improve the general function of the justice system and better safeguard the rights of litigants, which will then improve public trust. ${ }^{192}$

However, in light of the power consolidation that took place within the 2018 Amendments and the recent statement of President Xi Jinping condemning Western judicial review, ${ }^{193}$ it remains apparent that an independent system of review has yet to establish a foundation. President Xi's comments were in fact preceded by the Supreme People's Court Chief Judge Zhou Qiang at a meeting with other judges of the Supreme People's Court in 2017: "China's courts must firmly resist the Western idea of judicial independence and other ideologies that threaten the leadership of the ruling Communist Party ... People's Courts at all levels must disregard erroneous Western notions, including constitutional democracy and separation of powers." ${ }^{194}$ These comments were largely controversial and sparked public criticism seeking further checks and independence from the Communist Party. ${ }^{195}$ The article was soon deleted from various platforms. ${ }^{196}$

The Supreme People's Court responded to the public debate via four different publications, iterating its position on the CPC with each draft. ${ }^{197}$ The primary thesis was simple: "Creating a legal system independent of the party 'clearly violates the constitution,' which says administrative, trial and prosecution authorities are all subservient to the National People's Congress, China's parliament." "198 The implied necessity of a Constitutional amendment to justify a separately operated court system speaks to the rigid stance held by the unified government - the judiciary will be independent, but not from the

191. Xinhua, China Punishes 270 Court Officials in Three Years, The Supreme People's CT. of The People's RePublic of China, (Jan. 3, 2016), http://english.court.gov.cn/201601/03/content_23161287.htm [https://perma.cc/6H9W-2YDC].

192. See China Grants More Judicial Independence to Judges Amid Reform, supra note 189.

193. Xi, supra note 6.

194. Nicholas Heath, Lusha Zhang \& Christian Shepherd, China's Top Judge Warns Courts on Judicial Independence, REUTERS (Jan. 16, 2017), https://www.reuters.com/article/us-chinapolicy-law/chinas-top-judge-warns-courts-on-judicial-independence-idUSKBN1500OF [https://perma.cc/DFD6-EJSB].

195. Id. This statement was especially surprising to Western observers, as Judge Zhou Qiang was once seen as a constitutional reformist aspiring to ensure judicial independence. Jerome Cohen, a professor at NYU Law and expert on Chinese law, issued a response to this statement that spoke to its true social weight: "This statement is the most enormous ideological setback for decades of halting, uneven progress toward the creation of a professional, impartial judiciary." See also Lucy Hornby, China's Top Judge Denounces Judicial Independence, Financial Times (Jan. 17, 2017), https://www.ft.com/content/60dddd46-dc74-11e6-9d7c-be108f1c1dce [https:// perma.cc/QW7G-9WHA].

196. Heath, Zhang \& Shephard, supra note 195.

197. Id.

198. Id. 
Communist Party.

\section{CONCLUSION}

The fragmented development of constitutionalism in the PRC, marred by warring ideologies and subsequent deprivations of core human rights critical to the establishment of public trust has obstructed the foundation of baseline constitutional principles. ${ }^{199}$ Indeed, it is highly unlikely that a form of constitutionalism recognizable to Western $\mathrm{s}=$ States will develop in light of this new era of governance fostered by the CPC. On the contrary, the government has a strong commitment to enforce its own rule of law through a militant sort of constitutionalism, one that appears by and for the Party and its subsidiaries. The modern successes of the State in advancing this agenda speak volumes to China's capacity to sustain and promote this new era of governance. While Soviet and Western constitutionalism were the nation's initial aspirations, it may yet be that a new "constitutionalism"- a constitutionalism with Chinese characteristics - may be the new legal core of the People's Republic of China.

199. Shi, supra note 17. 